\title{
Evaluation of Thyroid-stimulating hormone in Sudanese children patients with malnutrition
}

\author{
Nuha Eljaili Abubaker (1) * Marwa Elhady Mohammed (2) \\ *kawthar Abdelgaleill MohammedSalih (2)
}

1. Sudan University of Science and Technology, College of medical Laboratory Science. Head Department of Clinical Chemistry.

2. Elneelin University, College of medical Laboratory Science

\section{Abstract}

\section{Background}

Malnutrition is defined as a state of nutrition in which a deficiency or imbalance of energy, protein shape, size and and other nutrients causes measurable adverse effects on tissue, body form (body composition) and function.

\section{Objective}

This study was carried out to measure serum levels of Thyroid stimulating hormone in malnutrition children.

\section{Materials and Methods:}

A total of one hundred and twenty subjects were enrolled in this study, divided into three group (thirty of them, moderately malnourished (BMI < 15), and thirty well nourished (BMI > 18) ) and thirty normal children as control, were collected from period between May to June 2017, chosen randomly from Mohammed AL Amin Hamid Hospital for Pediatric in Khartoum State (Sudan) , to assess Serum thyroid stimulating hormone in Sudanese children patients with malnutrition. Serum thyroid stimulating hormone was measured by using Enzyme Immune Sorbent Assay (ELISA) and results were analyzed using statistical of package social science (SPSS), computer program.

\section{Results}

The study showed that, Children with malnutrition had significantly high level in mean serum thyroid stimulating hormone in moderately malnourished compared to control group $(6.91 \pm .97$ versus $1.90 \pm 1.01, \mathrm{P}$ value $=0.000$ ) and there was significant increase in mean level of TSH hormone in well nourished compared to control group. ( $2.95 \pm 1.38$ versus $1.90 \pm 1.01$, P value $=0.001)$. Also the result showed, there was insignificant different in the mean of serum TSH in males compared to females children patients. Moderately malnourished (6.72 \pm 0.94$)(7.09 \pm 0.99)$, well nourished $(2.95 \pm 1.46)(2.95 \pm 1.34)$, with $\mathrm{P}$ value $(0.990)(0.298)$ respectively. There was significantly decrease in BMI in patients compared to control group. (Mean \pm SD: $15.28 \pm 2.28$ $\mathrm{kg} / \mathrm{m} 2$ versus $19.25 \pm 2.48 \mathrm{~kg} / \mathrm{m} 2$ ). In this study $50 \%$ of patient were males and $50 \%$ of patients were females. The result showed $28 \%$ of patients at age 7 years, $23 \%$ of patients at age 6 years, $19 \%$ of patients at 5 years, $11 \%$ of patients at 3 years and $3 \%$ of patients at 2 years.

\section{Conclusion}

In conclusion: Children with malnutrition had significantly high levels in means serum thyroid stimulating hormone (TSH) compared to control group.

Keywords: Protein energy malnutrition (PEM), Thyroid stimulating hormone (TSH) 


\section{Introduction}

Malnutrition is defined as a state of nutrition in which a deficiency or imbalance of energy, protein and other nutrients causes measurable adverse effects on tissue, body form(body shape, size and composition) and function. ${ }^{(1)}$

The World Health Organization defines malnutrition as "the cellular imbalance between supply of nutrients and energy and the body's demand for them to ensure growth, maintenance, and specific functions." (2)

Thyroid-stimulating hormone it is a glycoprotein hormone synthesized and secreted by thyrotrope cells in the anterior pituitary gland, which regulates the endocrine function of the thyroid. ${ }^{(3)(4)}$

Hypothyroidism The most common causes of hypothyroidism worldwide are dietary-protein malnutrition and iodine deficiency. This is because the two main ingredients needed to make thyroid hormone are tyrosine (an amino acid from dietary protein) and iodine (a naturally-occurring salt). ${ }^{(5)}$

when the body lacks one or more micronutrients (e.g. iron, iodine, zinc, vitamin A or folate). These deficiencies usually affect growth and immunity but some cause specific clinical conditions such as anaemia (iron deficiency), hypothyroidism (iodine deficiency) or xerophthalmia (vitamin A deficiency). ${ }^{(6)}$

The most common causes of hypothyroidism worldwide are dietary-protein malnutrition and iodine deficiency. This is because the two main ingredients needed to make thyroid hormone are tyrosine (an amino acid from dietary protein) and iodine (a naturally-occurring salt). ${ }^{\text {(7) }}$

Hypothyroidism, or underactive thyroid, develops when the thyroid gland fails to produce or secrete as much thyroxine $\left(T_{4}\right)$ as the body needs. Because $T_{4}$ regulates such essential functions as heart rate, digestion, physical growth, and mental development, an insufficient supply of this hormone can slow life-sustaining processes, damage organs and tissues in every part of the body, and lead to life-threatening complications ${ }^{(8)}$

Thyroid-stimulating hormone (also known as thyrotropin, thyrotropic hormone, TSH, or hTSH for human TSH) is a pituitary hormone that stimulates the thyroid gland to produce thyroxin $\left(\mathrm{T}_{4}\right)$, and then triiodothyronine $\left(\mathrm{T}_{3}\right)$ which stimulates the metabolism of almost every tissue in the body ${ }^{(9)}$ In PEM, there are marked changes in secretion and metabolism of thyroid hormones and in the structure of thyroid gland. This results in reduction of the activity of the gland (3), as the body tries to adapt to low calorie

intake. (9)

\section{Material and methods :}

Study Population: The study was carried out at College of Medical laboratory Sciences, and the subjects were recruited from Mohammed AL Amin Hamid Hospital for Pediatric in Khartoum State (Sudan) from January to August 2017. A total of 90 children were enrolled in this study ; divided into three groups, 30 healthy individual (Control group), 30 malnutrition with moderate nourished, and 30 children with will nourished. The study was approved by hospital's ethics committee. Informed consent was obtained from mothers of patients before blood sampling.

\section{Inclusion criteria:-}

Any patients with malnutrition agree to participate in study

\section{Exclusion criteria :}

Any patients with disease have relationship with Thyroid-stimulating hormone disturbance other than malnutrition.

Any patients take medication that can affect the result

Any patients refused to participate in the study were excluded . 


\section{Blood sample and analysis :-}

$3 \mathrm{ml}$ venous blood will obtain from artecubital vein by standard vein puncture technique without venous stasis. In serum separator tube, serum will be separated after 20 minute, the serum was separated by centrifugation. The estimation of the parameter was carried out within 4-6 hrs .Serum Thyroid-stimulating hormone (TSH) measured by ELIZA technique. ${ }^{(10)}$

Data was analyzed using SPSS computer program, the mean and standard deviation were obtained and the independent 't.test' used for comparison ( $p$ value of $\leq 0.05$ ) was considered significant.

\section{Results:-}

In comparison with the control, Children with malnutrition (moderately malnourished and well nourished) had significantly high levels in means serum thyroid stimulating hormone (6.91 \pm .97$)$ $(2.95 \pm 1.38) \mathrm{P}$ value (0.000) (0.001) respectively, as in table (1)

Table (1) :- means comparisons of serum TSH in malnutrition children compared to control group .

\begin{tabular}{|l|c|c|}
\hline TSH $(\boldsymbol{\mu} / \mathbf{L})$ & Mean \pm SD & P-value \\
\hline Control & $1.90 \pm 1.01$ & \\
\hline Moderate malnourished & $6.91 \pm 0.97$ & 0.000 \\
\hline Well malnourished & $2.95 \pm 1.38$ & 0.001 \\
\hline
\end{tabular}

There was insignificant different in the mean of serum TSH in males compared to females children patients. Male moderately malnourished (6.72 \pm 0.94$)$, well nourished $(2.95 \pm 1.46)$, while female moderately malnourished $(7.09 \pm 0.99)$, well nourished $(2.95 \pm 1.34)$.with P value (0.990) $(0.298)$ respectively as in table (2)

Table (2) :- means comparisons of serum TSH in malnutrition children compared to gender

\begin{tabular}{|l|c|c|c|}
\hline Variables & Male $($ Mean \pm SD) & Female $($ Mean \pm SD $)$ & $P$-value \\
\hline TSH $(\mu / \mathrm{L})$ moderate malnourished & $6.72 \pm 0.94$ & $7.09 \pm 0.99$ & 0.990 \\
\hline TSH $(\mu / \mathrm{L})$ well malnourished & $2.95 \pm 1.46$ & $2.95 \pm 1.34$ & 0.298 \\
\hline
\end{tabular}

Results expressed as Mean \pm SD and significant differences considered as p-value $\leq 0.05$.

In comparison of mean of BMI in malnourished children compared to control group the result showed, there was significantly decreased in BMI in patients compared to control group. (Mean \pm SD: $15.28 \pm 2.28 \mathrm{~kg} / \mathrm{m} 2$ versus $19.25 \pm 2.48 \mathrm{~kg} / \mathrm{m} 2)$ as in table (3).

Table (3): Mean of Body mass index (BMI) in malnourished children and control group.

\begin{tabular}{|l|l|l|l|}
\hline Variables & $\begin{array}{l}\text { Patients } \\
\text { N=60 } \\
\text { Mean } \pm \text { SD }\end{array}$ & $\begin{array}{l}\text { Control } \\
\text { N=60 } \\
\text { Mean } \pm \text { SD }\end{array}$ & p-value \\
\hline BMI $(\mathrm{Kg} / \mathrm{m} 2)$ & $15.28 \pm 2.28$ & $19.25 \pm 2.48$ & 0.000 \\
\hline
\end{tabular}

* Result given in mean $\pm \mathrm{SD}, \mathrm{P}$. value $\leq 0.05$ consider significant .

* Independent sample T test was used for comparison 


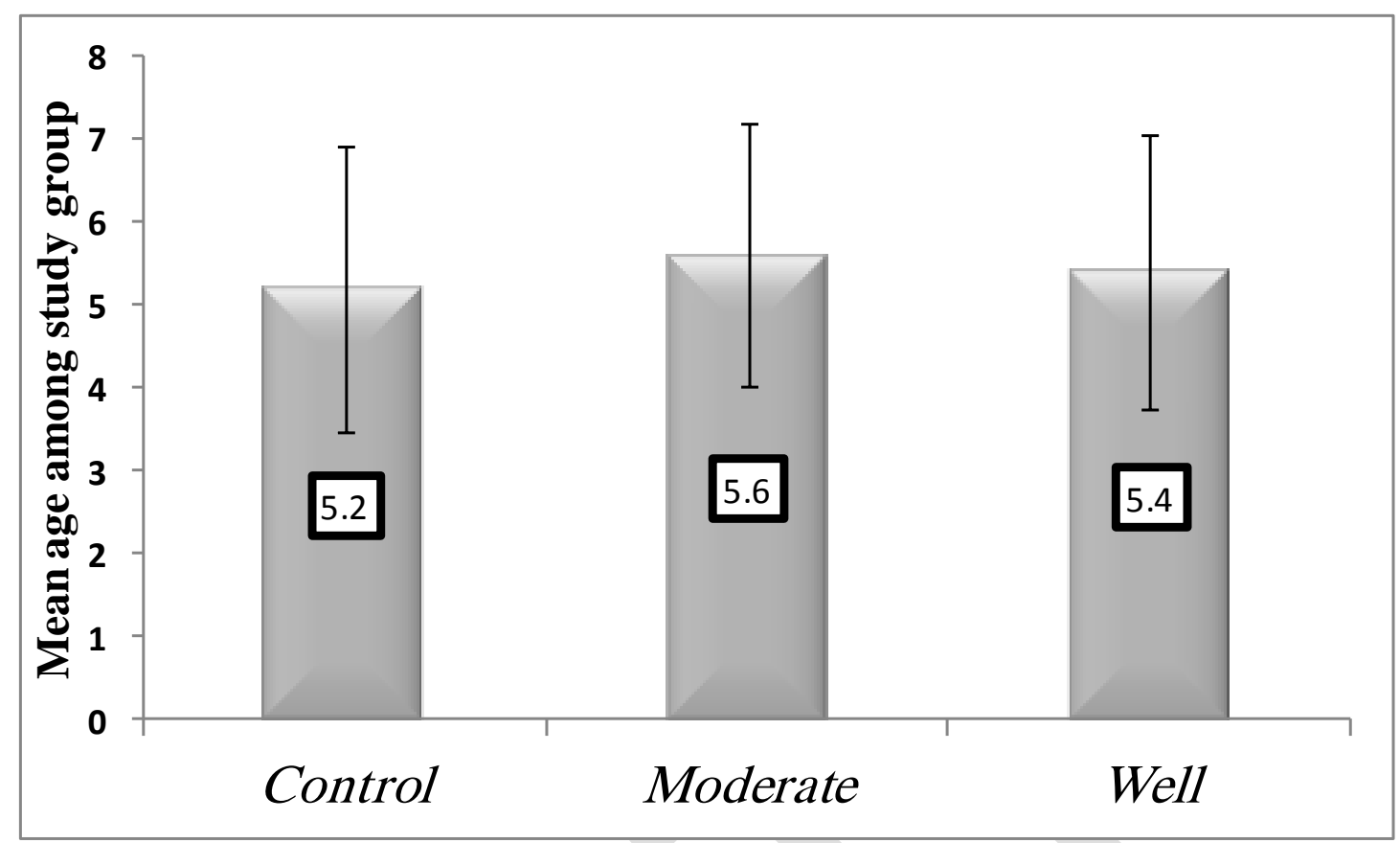

figure1:- Mean of age among study group.

The result showed $28 \%$ of patients at age 7 years, $23 \%$ of patients at 6 years ,19\% of patients at 5years , $16 \%$ of patients at age 4 years, $11 \%$ of patients at 3 years ,and $3 \%$ of patients at 2 years as in figure (2).

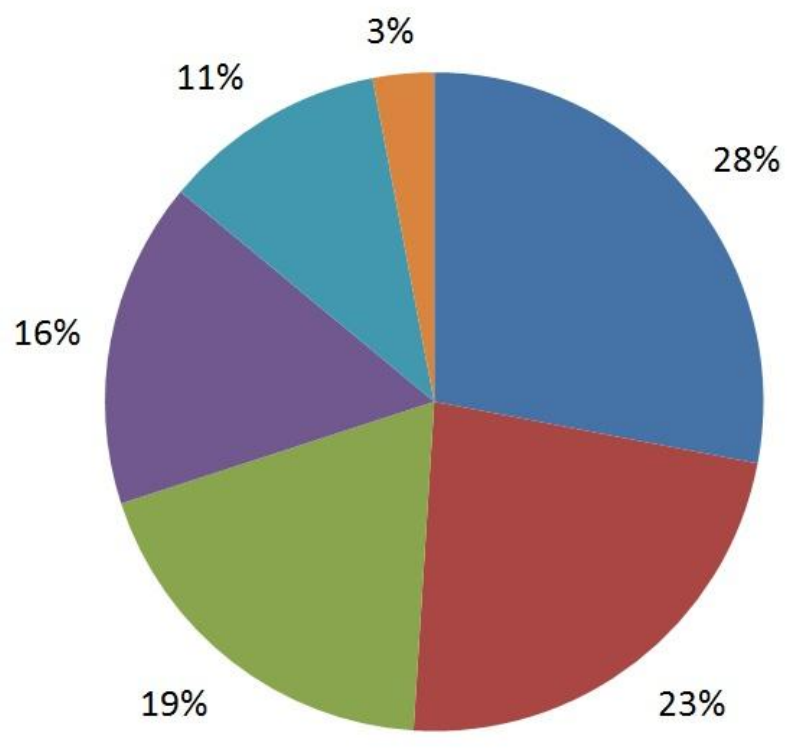

- 7 years

6 years

5 years

4 years

a 3 years

2 years

\section{Figure (2): Age distribution in case group.}

The result showed $50 \%$ of patients were males and $50 \%$ of patients were females as in figure (3) 


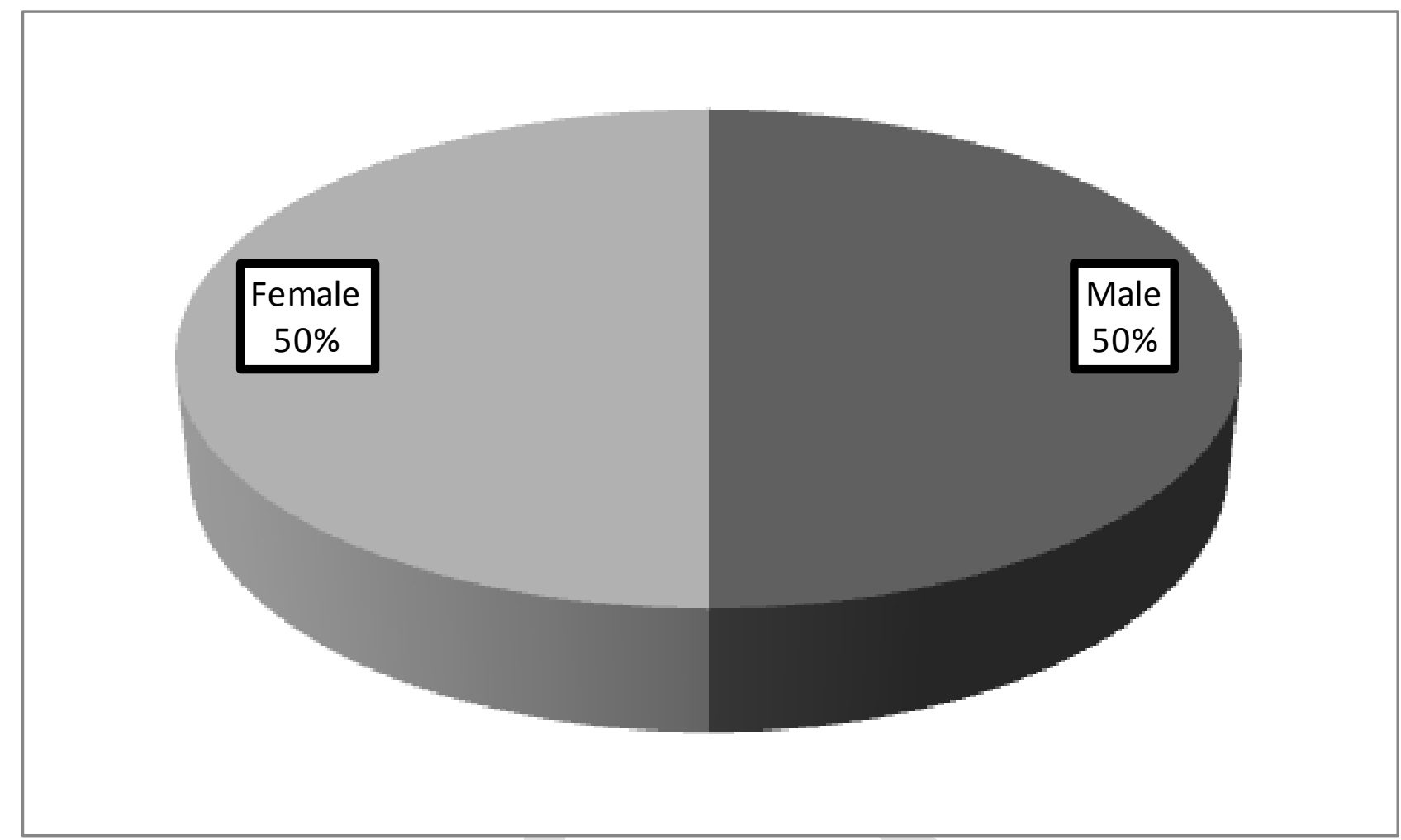

Figure (3):- Gender distribution in case group

\section{Discussion:-}

Malnutrition is currently the most widespread and serious health problem of children in the world. At any time approximately hundred million children suffer from the moderate or severe forms of malnutrition. ${ }^{(11)}$

This study was carried out to evaluate serum level of thyroid stimulating hormone (TSH) among Sudanese children with malnutrition in Khartoum state. The result of this study showed that, Children with malnutrition (moderately malnourished and well nourished )had significantly high level in means serum thyroid stimulating hormone compared to control group. ( $\mathrm{P}$, value $=0.00$ ). This result agreed with another result which finding similar result ${ }^{(12)}$. Also the result of this study is similar to another result which found that, the mean Of TSH level showed a positive increase with increase in severity of PEM with Maximum increase been observed in grade III PEM (Oneway ANOVA; $\mathrm{p}=0.015)^{(13)}$. Also the result similar to another study conducted by Shahjadi et al showed that, the mean serum TSH were $2.97 \pm 0.21 \mu \mathrm{IU} / \mathrm{L}, 4.98 \pm 0.32 \mu \mathrm{IU} / 1,5.02 \pm 0.29 \mu \mathrm{IU} / 1.6$ in group A (control group), B1 (marasmus group), B2 (kwashiorkor group) respectively; the mean \pm SD of serum TSH levels in group B1 and B2 were significantly higher $(p<0.001)$ than that of control $^{(14)}$. This result disagreed with another result carried by Gurdeep, which showed that, in PEM various endocrinal changes may be noted like decrease in growth hormone, normal or increase in adrenocortical activity and decrease in thyroid hormone. These changes are associated with reduced synthesis of plasma proteins which affects secretion and metabolism of these hormones ${ }^{(15)}$

This result disagreed with another result which found, TSH levels were significantly low in case group, when compared to the control group ( $\mathrm{p}<0.001)$. The levels of biochemical variables decreases as the severity of malnutrition increases. The difference within the cases (moderate and severe malnutrition) was also found to be statistically significant ( $\mathrm{p}<0.001)$. Result of this study disagreed to another result carried by Shaheen, which finding confirmed that, the mean of serum TSH level in cases and controls were within normal limits, though it was low normal in cases and 
high normal in controls. The levels decreases as the severity of malnutrition increases and the difference between the TSH levels among cases with moderate and severe malnutrition was statistically significant $(\mathrm{p}<0.001) .{ }^{(16)}$ The result disagreed with another result done by Abrol et al and Turkay et al, in their study found no significant difference in TSH when PEM children were compared to healthy controls ${ }^{(17)(18)}$

The result disagreed with another result which finding confirmed that, TSH levels were similar in both groups (malnourished children and control group). ${ }^{(19)}$ Also this result disagreed with another result which showed that, TSH levels were similar in PEM cases when compared to controls. ${ }^{(20)}$ Also this result disagreed with another result which found, PEM is associated with reduction in $\mathrm{T}_{3}$ and $\mathrm{T}_{4}$ levels without any alteration in TSH levels. The altered thyroid hormone status in children with PEM is perhaps a defense mechanism against excessive metabolic stimulation and energy consumption and protects the malnourished child with low calorie reserve from an early death. ${ }^{(21)}$ This study showed there was insignificant different in the mean of serum TSH in males compared to females children patients (moderately malnourished and well nourished children) (p, value $=0.990)(0.298)$ respectively.

This result agreed with result which found there was insignificant difference in the mean of serum TSH in males and females malnourished children. ${ }^{(22)}$ The study showed there was significantly decrease in the mean of BMI in patients compared to control group. This results agreed with a study carried by( Katherine, 2007), which showed that; body mass index decreased in malnourished children, because diarrhea results in large losses of water and nutrient from the body leading to weight loss. ${ }^{(23)}$

The result showed $28 \%$ of patients at age 7 years, $23 \%$ of patients at 6 years, $19 \%$ of patients at 5years, $16 \%$ of patients at age 4 years, $11 \%$ of patients at 3 years and $3 \%$ of patients at 2 years. This result similar to another result carried by many authors which showed that, malnutrition tendency to develop in lower aged group in African (Nigeria) and Asian (Bangladesh) countries. (5) (12) (24)

The finding obtained from especially designed questionnaire revealed that,(50\%) of patients were females and $(50 \%)$ of patients were males. This result disagreed with another study carried by ( kaneta) which showed that malnutrition most abundant in females than males. ${ }^{(25)}$

\section{Conclusion}

Thyroid-stimulating hormone (TSH) in Sudanese children patients with malnutrition is increased, there is no different in the mean of serum TSH in males compared to females children patients, the mean of BMI in malnutrition patients is decreased and malnutrition develop in lower aged group in Sudan.

\section{Acknowledgment}

We would like to express our appreciation to all participant in the study. We thank the staff of Mohammed AL Amin Hamid Hospital for Pediatric in Khartoum State (Sudan) and we appreciate the work for them. And also we thanks the staff of Research lab in College of Medical Laboratory Science in Sudan University of Science and Technology. Finally we appreciate everyone who support us.

\section{References:}

1-Mahaman, Y. A ., Akuyam ,S.A., Danborno, B., Galadima, O.M., Belemsigri, M and Moussa, S.M. Evaluation of some Laboratory Parameters of Malnourished Children in Magaria District, Zinder, Niger Republic.Sub-Saharan African Journal of Medicin. 2017;1(2):77-81.

2-Muller, O., Krawinkel, M. Malnutrition and health in developing countries.Can Med Ass $J$. 2005;171:279-293. 
3- -Freedman, D., Wang, J., Thornton, J., Mei, Z., Sopher, A and Pierson, R. Classification of body fatness by Body Mass Index-for-Age among children. Archives of Pediatric \& Adolescent Medicine. 2009;163(9), 805-811.

4 - Yasmeen, M . , Rehana ,M ., Mohammad, H. G. , Salma, S. Serum electrolytes changes in malnourished children with diarrhoea, pakistan journal of medical science ,profiessionalnedical publication. 2007; 23(5):1681-1715.

5--Chukwuma, B., Uche, R., Oluoha.,Kelechi, A., Uwakwe1., Kelvin, C., Diwe., Irene, A., Merenu., Ifeadike, O.,Chigozie, A., Anthony, $\mathbf{C}$ and Iwu. Prevalence and Sociodemographic Determinants of Malnutrition among Under-Five Children in Rural Communities in Imo State, Nigeria.Amer JPH R.2015; 3(6):199-206.

6-Black ,R.E, Allen, L.H., Bhutta, Z.A., Caulfield, L.E., De Onis, M., Ezzati, M., Mathers, C., Rivera, J. Maternal and Child Under nutrition: Global and Regional Exposures and Health Consequences. Maternal and Child Under nutrition Series. The Lancet 2008; 371:243-260

7-Almandoz, J.P and Gharib, H. Hypothyroidism: Etiology, Diagnosis, and Management. Med Clin N Am 2012; 96: 203-221.

8- Soeters, P.B., Reijven, P.L.M., van Bokhorst-de van der Schueren, M.A.E., Halfens, R.J.G., Meijers, J.M.M and van Gemert, W.G. A rational approach to nutritional assessment Clin.Nutr.2008; 27: 706-716.

9- kaneta, k ., Choudhury , M ., Hanifi , S and Abbas, A .gender inequality and severe malnutrition among children in a Remote Rural Area of Bangladesh .J health populnutr, center For Health and population Research. 2009; 18(3):123-130

10- Micheal, L.B., Edward, P.F and Larry,E.S. Clinical chemistry principles procedures correlations; $6^{\text {th }}$ ed. Lippincou Williams and Wilkins. 2010:328.

11- Iwu. Prevalence and Sociodemographic Determinants of Malnutrition among Under-Five Children in Rural Communities in Imo State, Nigeria.Amer JPH R. 2015 ; 3(6):199-206.

12- Irena, A.H.,Mwambazi, M. and Mulenga,V. Diarrhea is a major killer of children with severe acute malnutrition admitted to inpatient set-up in Lusaka, Zambia. NutrJ. 2011; 10(1):110. 13- Kumar,S., Nadkarni, J., Dwivedi, R. Thyroid hormone status in malnourished children.Indian Pediatr. 2009;46(3):263 -4

14 - Shahjadi S. Serum T3 and TSH level in severe PEM. J Dhaka Med Coll. 2011; 20 (2):174-7. 15 Gurdeep,S.,Dhanjal,I., Mrigind, S. Thyroid hormone status in children with protein energy malnutrition a hospital based case control study. Int J Contemp Pediatr. 2017 Mar;4(2):351-355

16 Shaheen, B., HajiI, M., Suma ,M.N. Serum FT3, FT4, TSH and proteins in children with protein energy malnutrition. Int J Pharm Bio Sci. 2013;4(3):834- 9..

17- Abrol P, Verma A, Hooda HS. Thyroid hormone status in protein energy malnutrition in Indian children. Indian J Clinical Biochemistry. 2001;16(2):221-3.

18-. Turkay S, Kus S, Gokalp A, Baskin E, Onal A. Effects of protein energy malnutrition on circulating thyroid hormones. Indian Pediatr. 1995;32(2):193-7.

19- Pankaj, A ., Ashok. , V and . Hooda ,H,S. Thyroid hormone status in protein energy malnutrition in Indian children, Indian J Clin Biochem. 2001 Jul; 16(2): 221-223.

20-Sandeep, M.., Krishnamurthy , B. Thyroid hormone status in children with protein energy malnutrition.IJCP.2016;3(1):91

21- Mishra,S.K.,Bastola,S.P and Jha.B. Biochemical nutritional indicators in children with protein energy malnutrition attending kanti children hospital, Kathmandu, Nepal.2009; 7(26):12934 . 
22- Adegbusi, H., Sule, M.S. Anthropometric and biochemical assessment among under five children in Kusada local government area, Katsina state, Nigeria. Bajopas. 2011;4(2):137-40.

23- Katherine, M.E. , Desha , N . , Tim, j .C. Body mass index cat off to define thinness in children and adolescent . International survey. 2007: 194- 204.

24- Jobiba, C., Andrew, T., Theresa, B., Catherine, M.P.F.(2008). The impact of HIV on mortality during in-patient rehabilitation of severely malnourished children in Malawi.Trans $R$ SocTrope Med Hyg; 102: 639-644.

25 - kaneta, k ., Choudhury ., M ., Hanifi , S and Abbas , A .gender inequality and severe malnutrition among children in a Remote Rural Area of Bangladesh.J health populnutr , center For Health and population Research. 2000; 18(3):123-130 . 